[Short Communication]

\section{A method for the cryopreservation of the pinewood nematode, Bursaphelenchus xylophilus}

\author{
Nobuo Ogura ${ }^{1}$
}

The pinewood nematode, Bursaphelenchus xylophilus (Steiner and Buhrer) Nickle, is usually maintained by continual subculturing on fungal cultures. A cryopreservation method for the nematode has been developed to avoid human error due to numerous and frequent passages on fungal cultures (Riga and Webster, 1991). The method is as follows. Nematodes are put into a 2 $\mathrm{ml}$ screw top tube with $1 \mathrm{ml}$ of $15 \%$ glycerol, 50 $\%$ M9 buffer ${ }^{2}$ and $35 \%$ S buffer ${ }^{3}$. The nematodes are stored in tubes for $24 \mathrm{hr}$ at $-70^{\circ} \mathrm{C}$ and then submerged in liquid nitrogen at $-180^{\circ} \mathrm{C}$. The percentage of motile juveniles after storage at $-180^{\circ} \mathrm{C}$ for 2 days was $4.8 \%$ in Ibaraki (Japan) isolate and $17.6 \%$ in St. William isolate (Riga and Webster, 1991). In this paper, another method was developed to increase percentage of live pinewood nematodes that pass through cryopreservation.

\section{MATERIALS AND METHODS}

Storage procedure:

The pinewood nematode (Ka-4 strain) isolated from dead Pinus densiflora Sieb. and Zucc. in Kasama City, Ibaraki Prefecture, 1994 (Kiyohara,T., pers. comm.) was used. The nema-

${ }^{1}$ Forestry and Forest Products Research Institute, P. O. Box 16, Tsukuba Norin-danchi, Ibaraki 305-8687, Japan. ${ }_{2}^{2} 6 \mathrm{~g} \mathrm{Na}_{2} \mathrm{HPO}_{4}, 3 \mathrm{~g} \mathrm{KH} \mathrm{PO}_{4}, 5 \mathrm{~g} \mathrm{NaCl}$ and $0.25 \mathrm{~g} \mathrm{MgSO}_{4} \cdot$ $7 \mathrm{H}_{2} \mathrm{O}$ per liter)

${ }^{3}(0.1 \mathrm{M} \mathrm{NaCl}$ and $0.05 \mathrm{M}$ potassium phosphate $(\mathrm{pH} 6.0))$

${ }^{4}\left(8.0 \mathrm{~g} \mathrm{NaCl}, 0.2 \mathrm{~g} \mathrm{KCl}, 0.115 \mathrm{~g} \mathrm{Na}_{2} \mathrm{HPO}_{4}, 0.2 \mathrm{~g} \mathrm{KH}_{2} \mathrm{PO}_{4}, 0.1 \mathrm{~g}\right.$

$\mathrm{CaCl}_{2}$ and $0.1 \mathrm{~g} \mathrm{MgCl}_{2} \cdot 6 \mathrm{H}_{2} \mathrm{O}$ per liter) tode was cultured on unidentified fungus growing on $4 \mathrm{ml}$ potato dextrose agar supplemented with yeast extract in culture bottle $(4.0 \times 7.5 \times$ height $2.0 \mathrm{~cm}$ ) (Ogura and Nakashima, 2002). The unidentified fungus was isolated from a dead juvenile of Contortylenchus genitalicola Kosaka and Ogura (Kosaka and Ogura, 1993). The cultured nematodes were isolated using an autoclaved $\left(120^{\circ} \mathrm{C}\right.$ for $\left.15 \mathrm{~min}\right)$ Baermann funnel and autoclaved distilled water (DW). One hundred $\mu \mathrm{l}$ of nematode suspension containing approximate 50,000 nematodes (mixture of juveniles and adults) were pored into a culture bottle $(4.0 \times 7.5 \times$ height $2.0 \mathrm{~cm})$ with $2 \mathrm{ml}$ of $25 \%$ glycerol in DW (Fig. 1). The glycerol solution was sterilized by passing through sterilized 0.2 $\mu \mathrm{m}$ filter. The nematodes were incubated for 24 hr at $15^{\circ} \mathrm{C}$ after which one-half volume of the $25 \%$ glycerol solution was discarded to increase the nematode density. The nematode suspension containing approximate 1,000 nematodes in 20 $\mu \mathrm{l}$ of $25 \%$ glycerol solution was pored onto an autoclaved paper disk (diameter $8 \mathrm{~mm}$, thickness $1.5 \mathrm{~mm}$ ) that was placed in a bottom of sterilized $2 \mathrm{ml}$ cryotube (Sarstedt, Germany). The cryotube with paper disc was pre-cooled on ice. Once prepared, the tubes with nematodes on paper disk were held for $24 \mathrm{hr}$ in a freezer ($25^{\circ} \mathrm{C}$ ). The tubes were then affixed to storage canes and submerged in a 20XT liquid nitrogen tank (Taylor-Wharton, USA).

Thawing procedure:

The cryotubes with the nematode samples were removed from liquid nitrogen after either $24 \mathrm{hr}$ or 6 months and $1.5 \mathrm{ml}$ of $25^{\circ} \mathrm{C}$ Dulbecco phosphate buffer saline ${ }^{4}$ was pored into the cryotube to thaw sample. Nematode viability was assessed $24 \mathrm{hr}$ after thawing by microscopic observation of motility. The mean \pm SD percentages of viable nematodes were calculated from 50 juvenile, 50 female adult and 50 male adult nematodes in each sample. The number of 


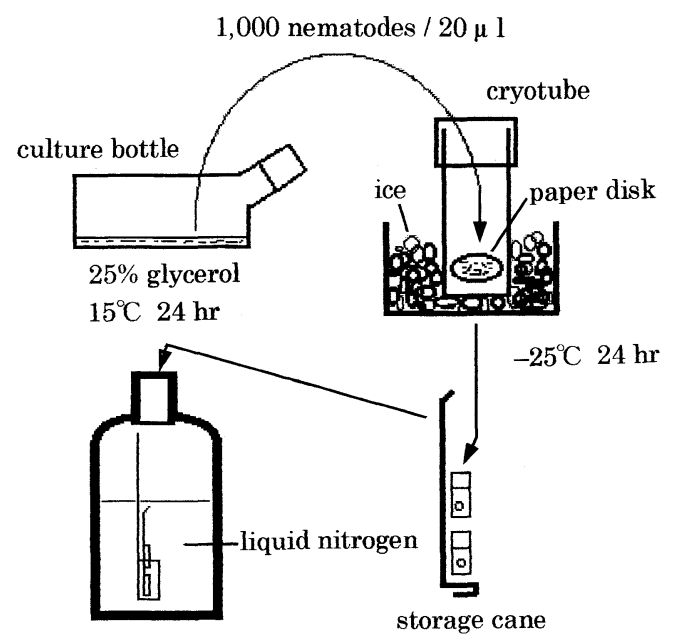

Fig. 1. Outline of the pinewood nematode-cryopreservation.

replicates was 3 .

Infection:

Fifty viable juveniles retrieved from samples that had been cryopreserved for 6 months were inoculated onto the fungus described. Cultured nematodes (1,000 nematodes) were reinoculated onto the fungus. Propagating nematodes were isolated 20 days after culturing at $25^{\circ} \mathrm{C}$ and suspended in DW $(5,000$ nematodes / $100 \mu \mathrm{l})$. Five, 5-year-old Japanese black pine, Pinus thunbergi Parl., grown in a nursery in Tsukuba City, Ibaraki Prefecture, were inoculated, as follows, with the nematodes on July 24, 2003. A shallow slit (ca $1 \mathrm{~cm}$ wide $\times 3 \mathrm{~cm}$ long) was made in the bark $30 \mathrm{~cm}$ from the base of the stem. A piece of filter paper (ca $0.8 \times 3 \mathrm{~cm}$ long) was inserted into the slit and $100 \mu$ of the nematode suspension containing 5,000 nematodes was placed between the filter paper and stem. The inoculation site was covered with Parafilm ${ }^{\circledR}$. Five pine trees were also inoculated with nematodes maintained on the unidentified fungus without cryopreservation. DW was also introduced into 5 pine trees as a DW-control. The number of replicates was 3 . Observation of pine for pine wilt were made 3 months after inoculation.

Analysis of variance (ANOVA) and Tukey HSD multiple comparisons were performed using SYSTAT. The analysis and comparisons of proportions were conducted using an arcsine transformation of the data.

\section{RESULTS AND DISCUSSION}

All of the juveniles and adults of the pinewood nematode held in suspension (50,000 nematodes / $2 \mathrm{ml}$ of $25 \%$ glycerol solution), that had been kept for $24 \mathrm{hr}$ at $15^{\circ} \mathrm{C}$ and then kept for $24 \mathrm{hr}$ at $-25^{\circ} \mathrm{C}$, died upon thawing (Ogura, personal observation). In the cryopreservation of Steinernema and Heterorhabditis spp., excess glycerol solution was removed by centrifugation (Popiel and Vasquez, 1991) or by suction filtration of the nematodes onto a filter paper supported in a Buchner funnel (Curran et al., 1992) before storage in liquid nitrogen. In this paper, excess glycerol solution was infiltrated into paper disk within the cryotube and then nematodes were pre-cooled for $24 \mathrm{hr}$ at $-25^{\circ} \mathrm{C}$. The removal of excess glycerol solution decreased the percentage of mortality in the pre-cooled nematodes (Ogura, personal observation). The mean percentages of motile juveniles, female adults and male adults after cryopreserving for 6 months were $60.3 \pm 4.6,39.7 \pm 5.6$ and 10.8 $\pm 3.9 \%$, respectively (Table 1 ). The percentages of motile juveniles, female adults and male

Table 1. Motility of cryopreserved Bursaphelenchus xylophilus $24 \mathrm{hr}$ after thawing.

\begin{tabular}{lcll}
\hline Storage & \multicolumn{3}{c}{ Motility (Mean \pm SD \%) } \\
\cline { 2 - 4 } period & Juveniles & $\begin{array}{l}\text { Female } \\
\text { adults }\end{array}$ & $\begin{array}{l}\text { Male } \\
\text { adults }\end{array}$ \\
\hline $24 \mathrm{hr}$ & $56.0 \pm 19.9 \mathrm{a}$ & $33.2 \pm 10.0 \mathrm{ab}$ & $10.8 \pm 3.7 \mathrm{~b}$ \\
6 months & $60.3 \pm 4.6 \mathrm{a}$ & $39.7 \pm 5.6 \mathrm{~b}$ & $10.8 \pm 3.9 \mathrm{c}$ \\
\hline
\end{tabular}

There was no storage period-dependent difference $(\mathrm{F}=0.609 ; \mathrm{df}=1,12 ; p=0.45)$. There was nematode-type dependent difference $(\mathrm{F}=40.47 ; \mathrm{df}=2,12 ; \quad p<0.001)$ (ANOVA, factor; storage period, nematode-type). The different letters in the same horizontal column show significant difference(TukeyHSD, $p<0.02$ ) 
adults cryopreserved for 6 months were not significantly different from those of motile juveniles, female adults and male adults cryopreserved for $24 \mathrm{hr}$, respectively. Those percentages were higher than the percentages reported by Riga and Webster (1991).

Pine wilt symptoms were observed on $80 \pm$ $0 \%$ of pines inoculated with the cryopreserved nematodes and $91 \pm 36 \%$ of pines inoculated with non-cryopreserved nematodes 3 months after inoculation. None of pines inoculated with DW had symptoms. There was an inoculumdependent difference (ANOVA, factor; inoculum, $\mathrm{F}=23.966, \mathrm{df}=2,6, p=0.001$ ). There was, however, no significant difference between cryopreserved and non-cryopreserved nematodes (Tukey HSD, $p=0.483)$. This result suggests that cryopreservation does not affect the pathogenicity of the pinewood nematode.

Consequently, the cryopreservation method for the pinewood nematode developed in this paper may be simple and available. Experiments are now continued to confirm a viability of the nematode cryopreserved for longer periods.

\section{ACKNOWLEGDEMENT}

I thank Professor M. J. Linit, University of Missouri-Columbia, and Professor R. I. Bolla, Youngstown State University, for reviewing an earlier version of the manuscript.

\section{LITERATURE CITED}

Curran, J., Gilbert, C. and Butler, K. (1992) Routine cryopreservation of isolates of Steinernema and Heterorhabditis spp. Journal of Nematology 24, 269 - 270.

Kosaka, H. and Ogura, N. (1993) Contortylenchus genitalicola n. sp. (Tylenchida : Allantonematidae) from the Japanese pine sawyer, Monochamus alternatus (Coleoptera: Cerambycidae). Applied Entomology and Zoology 28, 423 - 432.
Ogura, N. and Nakashima, T. (2002) In vitro occurrence of dispersal fourth stage juveniles in Bursaphelenchus xylophilus co-incubated with Monochamus alternatus. Japanese Journal of Nematology 32, 53 - 59.

Popiel, I. and Vasquez, E. M. (1991) Cryopreservation of Steinernema carpocapsae and Heterorhabditis bacteriophora. Journal of Nematology 23, 432 - 437.

Riga, E. and Webster, J. M. (1991) Cryopreservation of the pinewood nematode, Bursaphelenchus spp. Journal of Nematology 23, 438 - 440.

Received October 24, 2003.

\section{和文摘要}

\section{マツノザイセンチュウの凍結保存法}

小倉信夫

マツノザイセンチュウ（センチュウと略す） の凍結保存法の開発に取り組んだ。ベールマン 法で分離したセンチュウをグリセリン水溶液 （25\%）に懸濁して 24 時間 $15^{\circ} \mathrm{C} て ゙$ 保った。次に、 センチュウ約 1,000 頭を含むグリセリン水溶液 20 $\mu$ lを凍結保存チューブ（容量 $2 \mathrm{ml}$ ) の底に敷いた ペーパーデイスクに滴下して、 24 時間 $-25^{\circ} \mathrm{C} て ゙$ 保った後、この凍結保存チューブを液体窒素に 沈めて保存した。6ケ月後にチューブを取り出し て $25^{\circ} \mathrm{C}$ のDulbeccoのリン酸緩衝塩類溶液をチュー ブ内に注いでセンチュウを解凍した。センチュ ウ幼虫の生存率は約 $60 \%$ であった。解凍したセ ンチュウを増殖して 5,000 頭ずつ 5 年生クロマツ に接種したところ、80\%のクロマツが枯死した。 今回開発した凍結保存法では、解凍後の生存率 は比較的高く、解凍後に増殖したセンチュウの 病原力は損なわれていなかった。 